\title{
Physiological responses of 'Arbequina' olive trees to summer deficit irrigation
}

\author{
A. Centeno and M. Gómez del Campo \\ Departamento de Producción Agraria, Universidad Politécnica de Madrid, Spain
}

Keywords: Stomatal conductance, relative extractable water, stem water potential, Olea europaea L., vapour pressure deficit, atmospheric conditions.

\begin{abstract}
Most olive growing areas in the Mediterranean region are characterized by scarce water resources, especially in summer. This lack of water negatively affects the physiological development of the plant and thus its productivity. However olive tree seems to be less sensitive to water stress during summer. To evaluate the physiological responses of olive trees to water stress during this period three deficit irrigation treatments were applied. Control trees (CON) were irrigated to maintain the root zone close to field capacity. Two severe water deficit treatments were applied during summer by irrigating $30 \%$ CON in July ( $1^{\text {st }}$ period) in DI-J or in August ( $2^{\text {nd }}$ period) in DI-A. Moderate water deficit was applied from July to August (1 $1^{\text {st }}$ and $2^{\text {nd }}$ periods) by irrigating $50 \%$ CON in DI-JA. Midday stem water potential ( $\Psi s$ ) and stomatal conductance (g) were measured during the irrigation period. Relative extractable water (REW) was determined from soil water content. Vapour pressure deficit (VPD) and ETo were calculated. The irrigation treatments modified g during summer, in response to the different amounts of water applied. When irrigation was reestablished these differences between treatments disappeared, showing a high capacity of the olive tree for a use of water when this is available. In moderate stresses trees ( $\Psi s>-1.5 \mathrm{MPa}) \mathrm{g}$ was linearly and curvilinearly related to REW and VPD respectively. Only when water atmospheric demand was lower than $5.5 \mathrm{~mm}^{\cdot \mathrm{d}^{-1}}$, $\mathrm{g}$ was significantly correlated with $\Psi$ s.
\end{abstract}

\section{INTRODUCTION}

Although olive tree develops physiological and morphological mechanisms of adaptation to water-limited conditions (Connor, 2005), it responds positively to irrigation even applied at deficit, improving its productivity. However, the water resources are scarce in the most areas where olive orchards are established. In this idea, regulated deficit irrigation (RDI) is an irrigation strategy based on the reduction of irrigation quantity in certain periods such that final fruit growth and production are least reduced (Fereres and Soriano, 2007). Different experiments have demonstrated that the less susceptible period to water reduction in olive tree occurs in summer (Lavee et al., 2007). Between budburst and fruit drop many physiological processes determine the ultimate fruit number (Pastor, 2005) and a lack of water could reduce fruit production, and from the end of summer and harvest oil is synthetized and water starvation could negatively affect to oil synthesis and quality (Martin-Vertedor et al., 2011).

Stem water potential, stomatal conductance and photosynthesis have been widely reported as being very sensitive to water stress conditions in olive trees (Fernández et al., 2006; Moriana et al., 2010). During periods of moderate water stress, olive trees typically experience reductions in gas exchange to optimize water use in drought conditions (Giorio

a E-mail: ana.centeno@upm.es 
et al., 1999). Atmospheric evaporative demand and soil moisture also have a high influence in plant water status.

The purpose of this work was to evaluate the physiological responses of 'Arbequina' hedgerow olive trees to RDI applied in different summer periods and intensities. Plant growth, production and olive fruit development response to these deficit irrigation treatments have already been published by Gómez del Campo (2013a, b) and Gómez del Campo et al. (2014).

\section{MATERIALS AND METHODS}

The experiment was carried out from 2007 to 2009 at a commercial olive orchard (cv. Arbequina) planted in 1997 in Puebla de Montalbán, Toledo, Spain, at a spacing of 4 x 2 $\mathrm{m}$. Soil was clay loam (Haploxeralf typic) with an effective rooting depth of $0.60 \mathrm{~m}$. Weather parameters were obtained from an automatic weather station located some $40 \mathrm{~m}$ away from the experimental trees. Thirty-minute averages of temperature, relative humidity, global solar radiation, wind speed and rainfall were recorded. Vapour pressure deficit (VDP) and ETo were calculated (ETo by the Penman Monteith method; Allen et al., 1998) from these climatic variables.

Four irrigation treatments (CON, DI-J, DI-A and DI-JA) were established in a completely randomized four block design. Irrigation was by drip emitters of $3 \mathrm{~L} / \mathrm{h}$ spaced $0.50 \mathrm{~m}$ apart. Control trees $(\mathrm{CON})$ were irrigated to maintain the root zone close to field capacity. Two severe water deficit treatments were applied during summer by irrigating $30 \%$ CON in July (1 $1^{\text {st }}$ period) in DI-J or in August ( $2^{\text {nd }}$ period) in DI-A. Moderate water deficit was applied from July to August $\left(1^{\text {st }}\right.$ and $2^{\text {nd }}$ periods) by irrigating $50 \%$ CON in DI-JA. Further details of irrigation treatments and climatic conditions were reported by Gomezdel-Campo (2013a).

Soil water content $\left(\theta, \mathrm{m}^{3} / \mathrm{m}^{3}\right)$ was measured hourly with four sensors using a capacitance probe (Enviroscan, Sentek Pty. Ltd, Australia). Relative extractable water (REW) was calculated by the equation $\operatorname{REW}=\left(\theta-\theta_{\min }\right) /\left(\theta_{\max }-\theta_{\min }\right)$, where $\theta$ is the actual soil water content, $\theta_{\max }$ and $\theta_{\min }$ were the maximum and minimum soil water content measured during the experiment in each tube, respectively.

Midday stem water potential ( $\Psi \mathrm{s}, \mathrm{MPa}$ ) was measured on four shoot tips per treatment located on shaded branches near the trunk with a pressure chamber (Soil Moisture Equip., Santa Barbara, CA, USA) every two weeks during the irrigation period. Shoot tips were covered with aluminum foil at least $1 \mathrm{~h}$ prior excision.

Midday stomatal conductance to $\mathrm{H}_{2} \mathrm{O}\left(\mathrm{g}\right.$, $\left.\mathrm{mmol} \mathrm{m}^{-2} \cdot \mathrm{s}^{-1}\right)$ was measured with a steadystate porometer (LI-1600, LICOR, Lincoln, NE, USA) in 2007 and with a portable photosynthetic system (CIRAS-2, PP Systems, Amesbury, MA, USA) in 2009.

Data were subjected to analysis of variance using MSTAT-C (University of Michigan, USA). Least significant differences $(P<0.05)$ were used to separate treatment means using Duncan's multiple range test.

\section{RESULTS AND DISCUSSION}

The irrigation treatments applied during summer significantly decreased $\Psi_{\mathrm{s}}$ (Gomez del Campo, 2013b) and g (Fig. 1) when water restriction was imposed. In 2007, the highest g

a E-mail: ana.centeno@upm.es 
values were recorded on 31/7 and 30/8 (Fig. 1a), coinciding with an increase in the soil water content (Gomez del Campo, 2013b). In the $1^{\text {st }}$ period DI-J and DI-JA received $70 \%$ and $50 \%$ lower irrigation than CON however significant differences between treatments were not observed. In the $2^{\text {nd }}$ period in spite of irrigation in DI-J was similar to CON, g was significantly lower than CON until 10 days after rewatering coinciding with a decrease of VPD values. In DI-A and DI-JA g was significantly lower than CON and DI-J until mid-October although irrigation dose was increased from beginning of September. Olive trees did not show a quick recovery in $g$ when water became available, probably because of the low hydraulic conductance of the xylem, which may be responsible for the tree to prevent at least, in part, water loss under high atmospheric evaporative demand (Rieger, 1985). However $\Psi_{s}$ showed a quick recovery after rehydration (Gomez del Campo, 2013b). In 2009 , the highest value of $\mathrm{g}$ was recorded on $2 / 7$ in the most irrigated treatments in the $1^{\text {st }}$ period (CON and DI-A) (Fig. 1b), however $g$ was decreasing after that in all treatments even when water application increased in DI-J in the $2^{\text {nd }}$ period. Differences between treatments were observed when water was reduced but when irrigation was similar to CON these differences disappeared. Pérez-Lopez et al. (2008) observed that the recovery of leaf gas exchange was related to the level of water stress reached previously and they obtained a delay in g recovery when olive trees were irrigated with low water doses from $\Psi_{s}$ values lower than -3.6 MPa. In the present work, minimum $\Psi$ s value registered was lower than -3.8 MPa (Gomez del Campo, 2013b).

No relationship was found between $\mathrm{g}$ and REW or VPD when all data were considered in 2007 and 2009. However in 2009, these relationships were significant when plant water status was considered. For high plant hydration status ( $\left.\Psi_{\mathrm{s}}>-1.5 \mathrm{MPa}\right) \mathrm{g}$ significantly decreased when REW was reduced $\left(\mathrm{R}^{2}=0.79\right)$ (Fig. 2) and when VPD increased $\left(\mathrm{R}^{2}=0.9\right)$ (Fig. 3), whereas in stressed plants no relationships between these parameters were found. The dependence between g-VPD relationship and olive water status level had been reported in olive by Moriana et al. (2002). These authors did not obtained a significant relationship between $g$ and VPD when olive trees presented $\Psi_{s}$ values lower than $-4 \mathrm{MPa}$.

The relationship between $g$ and $\Psi$ s was not significant either for the whole pool of data or in treatments individually, nevertheless this relationship was significant in the two years of experiments $\left(\mathrm{R}^{2}=0.63\right)$ when water atmospheric demand level was considered (ETo $<5.5 \mathrm{~mm} \cdot \mathrm{d}^{-1}$ ) (Fig. 4). In this condition g decreased as $\Psi \mathrm{s}$ was lower. This shows that olive trees restricted water loss on a day of high atmospheric water demand by closing the stomata, preventing an excessive drop in Ys (Fernández et al., 1997). Tardieu (1993) pointed out that stomata close at a threshold leaf water potential, but it is difficult to account for the fact that the threshold changes with evaporative demand.

Stomata are integrators of all environmental factors affecting plant growth (Morison, 1998). For this reason the most severe atmospheric conditions registered in 2009 (a summer ETo and VPD of $8.4 \mathrm{~mm}$ and $2.5 \mathrm{kPa}$, respectively) regarding 2007 (summer ETo and VPD of $5.8 \mathrm{~mm}$ and $2.0 \mathrm{kPa}$ ) could explain the high limitations of these conditions in the stomatal aperture the second year of experiment.

\section{CONCLUSIONS}

Water stress applied in summer has decreased $g$ when water starvation was imposed. Although irrigation was reestablished a delay in g recovery was observed probably because olive trees presented very low $\Psi_{\mathrm{s}}$ values before rehydration $\left(\Psi_{\mathrm{S}}<-3.8 \mathrm{MPa}\right)$.

a E-mail: ana.centeno@upm.es 
Only when plants presented a moderate stress ( $\left.\Psi_{\mathrm{S}}>-1.5 \mathrm{MPa}\right) \mathrm{g}$ was significantly correlated with REW and VPD, showing the dependence of the level of plant water stress on leaf gas exchange. With high evaporative demand (ETo>5.5 $\mathrm{mm} \mathrm{d}-1$ ) g- $\Psi$ s relationship was not significant. This demonstrated the high influence of environmental factors on stomatal opening.

\section{ACKNOWLEDGEMENTS}

We gratefully acknowledge Casas de Hualdo for access to the olive orchard and Regaber SA for irrigation equipment. This research was funded by UPM (AL10-PID-20, AL11-P(I+D)-19).

\section{Literature Cited}

Allen, R.G., Pereira, L.S., Raes, D. and Smith, M. (1998). Crop evapotranspiration. Guidelines for computing crop water requirements. Irrigation and drainage paper 56. FAO, Rome.

Connor, D.J. (2005). Adaptation of olive (Olea europaea L.) to water-limited environments. Austr. J. Agric. Res. 56, 1181-1189. http://dx.doi.org/10.1071/ar05169.

Fereres, E. and Soriano, M.A. (2007). Deficit irrigation for reducing agricultural water use. J. Exp. Botany 58, 147-159. http://dx.doi.org/10.1093/jxb/erl165.

Fernández, J.E., Moreno, F., Girón, I.F. and Blázquez, O.M. (1997). Stomatal control of water use in olive tree leaves. Plant and Soil 190, 179-192.

Fernández, J.E., Díaz-Espejo, A., Infante, J.M., Durán, P., Palomo, M.J., Chamorro, V., Girón, I.F. and Villagarcía, L. (2006). Water relations and gas exchange in olive trees under regulated deficit irrigation and partial rootzone drying. Plant and Soil 284, 273-291. http://dx.doi.org/10.1007/s11104-006-0045-9.

Giorio, P., Soventino, G. and d'Andria, R. (1999). Stomatal behaviour, leaf water status and photosynthetic response in field-grown olive trees under water deficit. Agric. Water Manag. 42, 95-104. http://dx.doi.org/10.1016/s0098-8472(99)00023-4.

Gómez-del-Campo, M. (2013a). Summer deficit-irrigation strategies in a hedgerow olive orchard cv. Arbequina: effect on fruit characteristics and yield. Irrig. Sci. 31, 259-269. http://dx.doi.org/10.1007/s00271-011-0299-8.

Gómez-del-Campo, M. (2013b). Summer deficit irrigation in a hedgerow olive orchard cv. Arbequina: relationship between soil and tree water status, and growth and yield components. Span. J. Agr. Res. 11, 547-557. http://dx.doi.org/10.5424/sjar/ 2013112-3360.

Gómez-del-Campo, M., Pérez-Expósito, M.A., Hammami, S.B.M., Centeno, A. and Rapoport, H.F. (2014). Effect of varied summer deficit irrigation on components of olive fruit growth and development. Agric. Water Manag. 137, 84-91. http://dx.doi.org/ 10.1016/j.agwat.2014.02.009.

Lavee, S., Hanoch, E., Wodner, M. and Abramowitch, H. (2007). The effect of pre-determined deficit irrigation on the performance of cv. 'Muhasan' olives (Olea europaea L.) in the eastern coastal plain of Israel. Sci. Hortic. 112, 156-163. http://dx.doi.org/10.1016/ j.scienta.2006.12.017.

a E-mail: ana.centeno@upm.es 
Martin-Vertedor, A.I., Pérez, J.M., Prieto, H. and Fereres, E. (2011). Interactive responses to water deficits and crop load in olive (Olea europaea L., cv. Morisca). II: Water use, fruit and oil yield. Agric. Water Manag. 98, 950-958. http://dx.doi.org/10.1016/ j.agwat.2011.01.003.

Moriana, A., Villalobos, F.J. and Fereres, E. (2002). Stomatal and photosynthetic responses of olive (Olea europaea L.) leaves to water deficits. Plant, Cell and Environ. 25, 395-405. http://dx.doi.org/10.1046/j.0016-8025.2001.00822.x.

Moriana, A., Girón, I.F., Martín-Palomo, M.J., Conejero, W., Ortuño, M.F., Torrecillas, A. and Moreno, F. (2010). New approach for olive trees irrigation scheduling using trunk diameter sensors. Agric. Water Manag. 97, 1822-1828. http://dx.doi.org/10.1016/j.agwat.2010.06. 022.

Morison, JIL. (1998). Stomatal response to increased CO2 concentration. J. Exp. Bot. 49, 443452. http://dx.doi.org/10.1093/jexbot/49.suppl_1.443.

Pastor, M. (2005). Cultivo del olivo con riego localizado. Mundi-Prensa, Madrid.

Pérez-López, D., Gijón, M.C. and Moriana, A. (2008). Influence of irrigation rate on the rehydration of olive tree plantlets. Agric. Water Manag. 95, 1161-1166. http:// dx.doi.org/ 10.1016/j.agwat.2008.04.012.

Rieger, M. (1985). Offsetting effects of reduced root hydraulic conductivity and osmotic adjustement following drought. Tree Physiol. 15, 379-385. http://dx.doi.org/10.1093/ treephys/15.6.379.

Tardieu, F. (1993). Will increases in our understanding of soil-root relations and root signalling substantially alter water flux models?. Philosophical Transactions of the Royal Society of London, B: Biological Sciences 341, 57-66. http://dx.doi.org/10.1098/ rstb.1993.0091.

a E-mail: ana.centeno@upm.es 


\section{Figures}
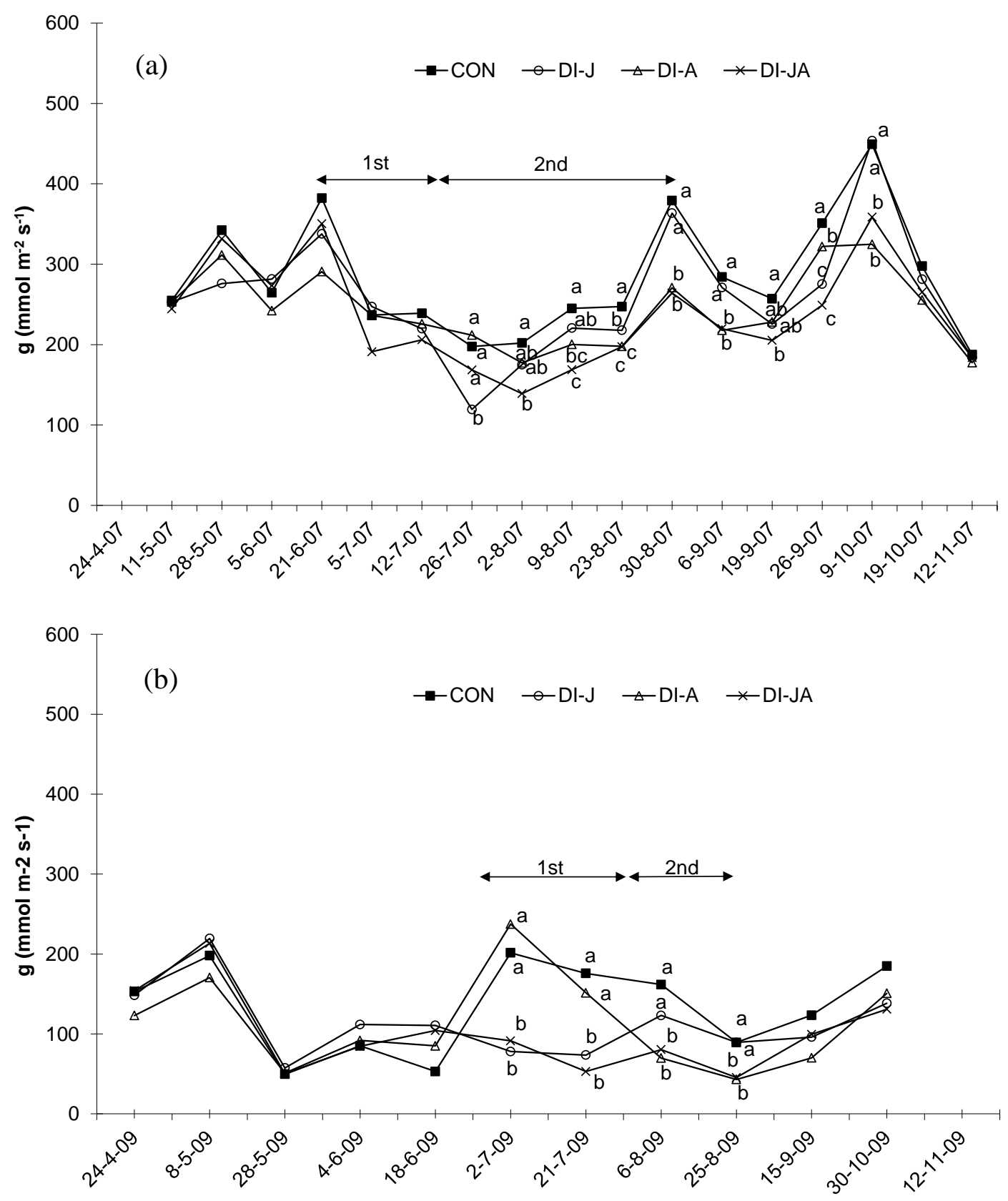

Fig. 1. Evolution of leaf conductance $\left(\mathrm{g}, \mathrm{mmolH}_{2} \mathrm{Om}^{-2} \mathrm{~s}^{-1}\right)$ at solar noon in a control $\mathrm{CON}$ and three deficit-irrigation treatments (DI-J, DI-A and DI-JA) during 2007 (a) and 2009 (b). Arrows indicate $1^{\text {st }}$ (July) and $2^{\text {nd }}$ (August) summer periods with water restriction. Treatments with the same letter are not significantly different by Duncan's test at $p<0.05$. Values are means of 4 replicates. 


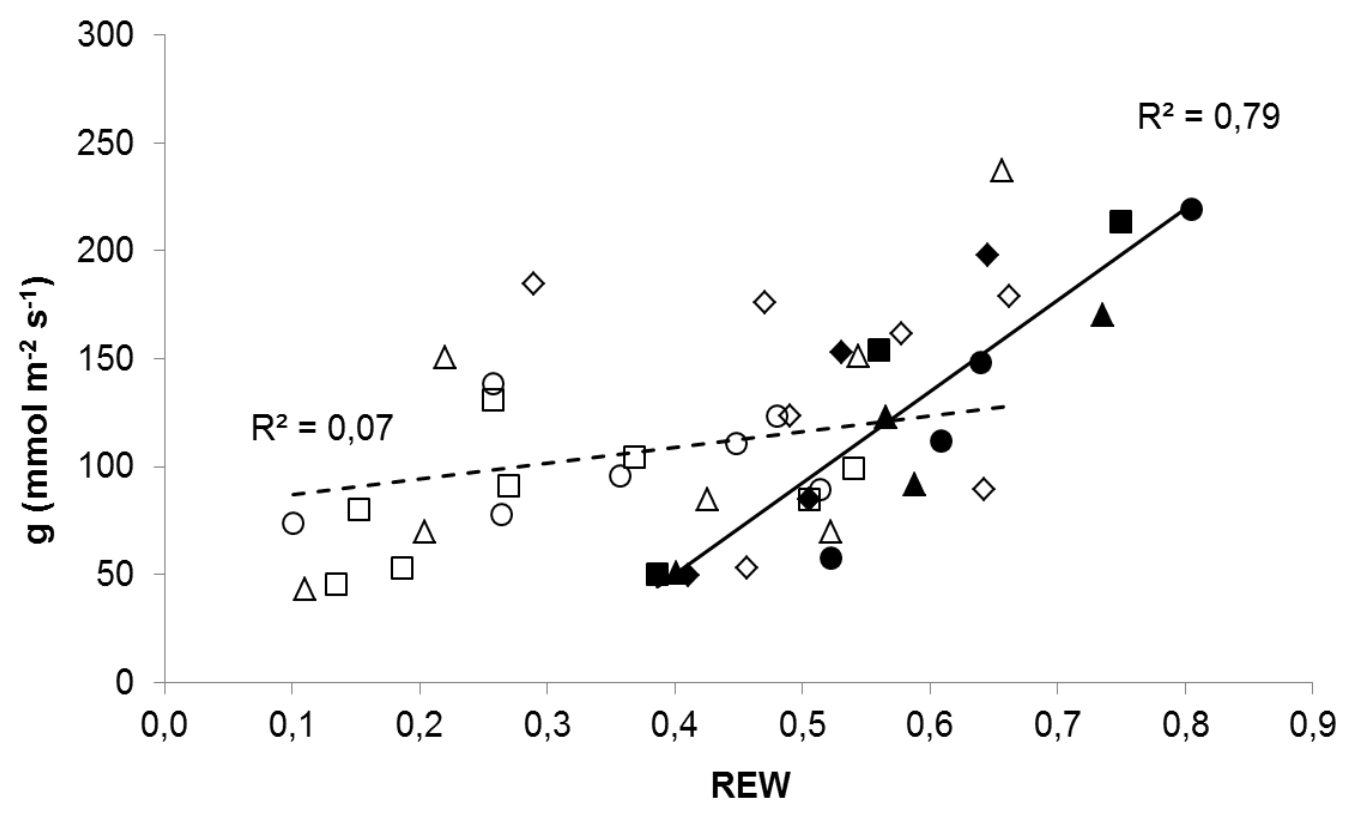

Fig. 2. Relationship between relative extractable water (REW) and midday stomatal conductance (g, mmol $\mathrm{H}_{2} \mathrm{Om}^{-2} \mathrm{~s}^{-1}$ ) in CON (diamond), DI-J (triangle), DI-A (circle) and DI-JA (square) for two different levels of stem water potential, $\Psi_{\mathrm{s}}>-1.5 \mathrm{MPa}$ (solid) and $\Psi_{\mathrm{s}}<-1.5 \mathrm{MPa}$ (clear). Each point represents the average of four measures per treatment taken in 2009.

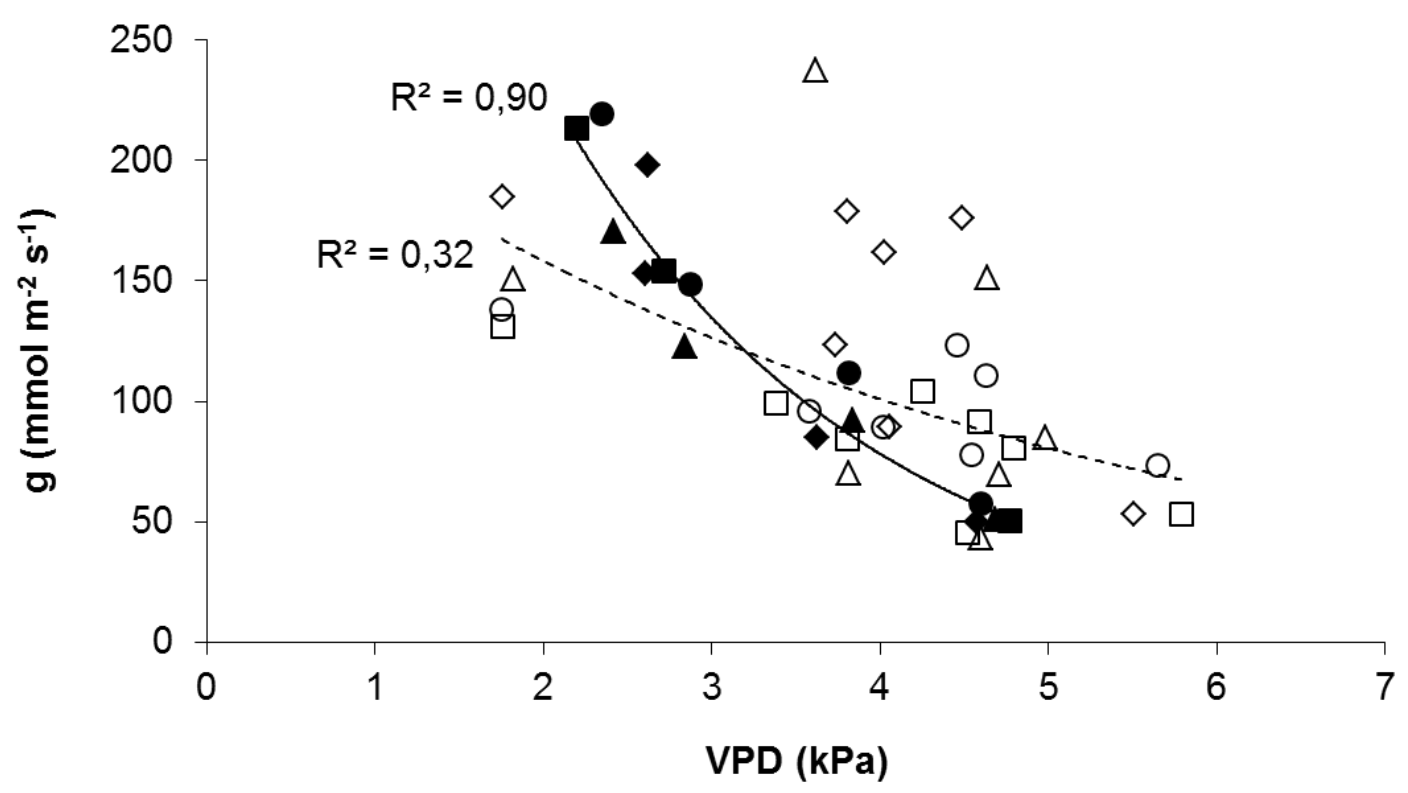

Fig. 3. Relationship between VPD (kPa) and midday stomatal conductance (g, mmol m $\left.\mathrm{m}^{-2} \mathrm{~s}^{-1}\right)$ in CON (diamond), DI-J (triangle), DI-A (circle) and DI-JA (square) for two different levels of stem water potential, $\Psi_{\mathrm{S}}>-1.5 \mathrm{MPa}$ (solid) and $\Psi_{\mathrm{S}}<-1.5 \mathrm{MPa}$ (clear). Each point represents the average of four measures per treatment taken in 2009.

a E-mail: ana.centeno@upm.es 


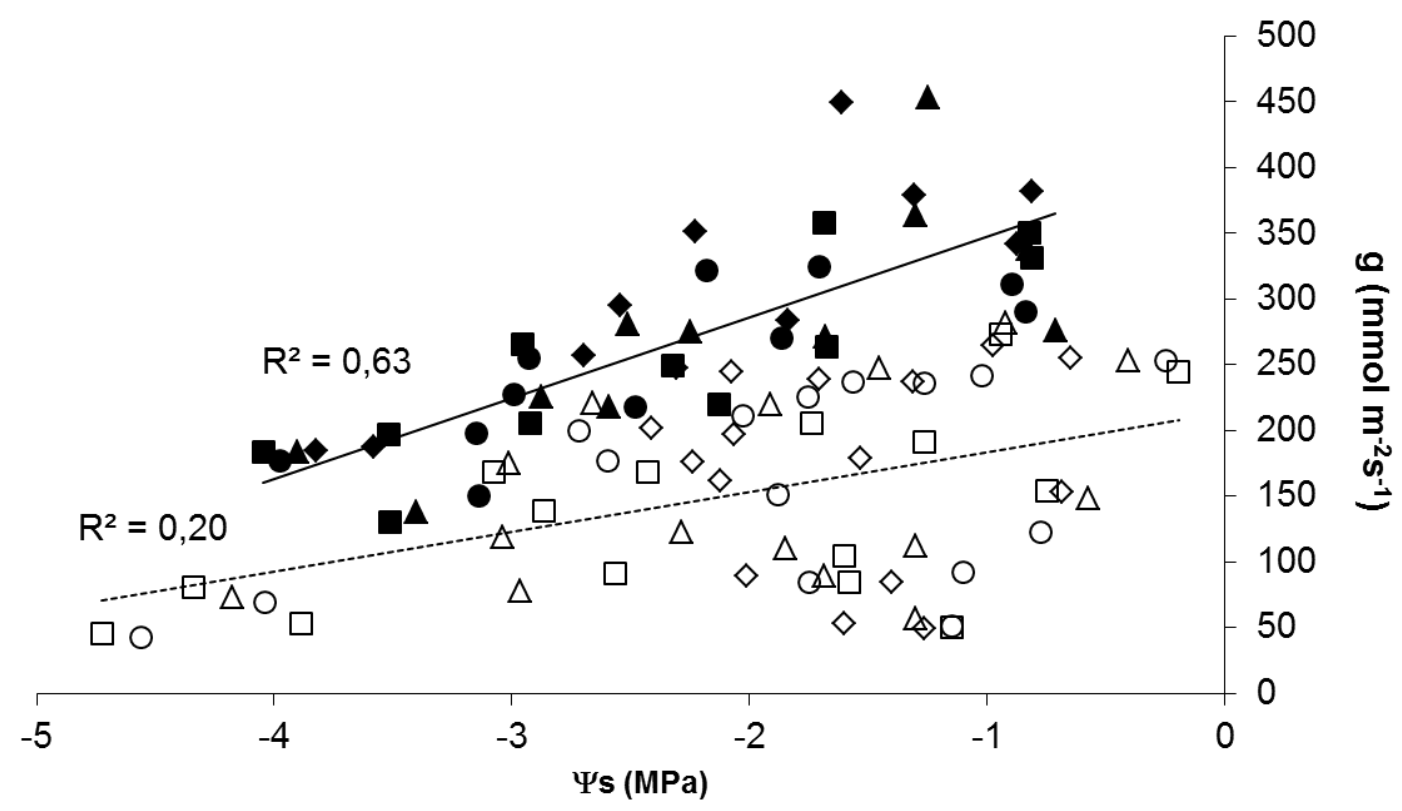

Fig. 4. Relationship between stem water potential ( $\left.\Psi_{\mathrm{s}}, \mathrm{MPa}\right)$ and stomatal conductance (g, mmol m $\mathrm{m}^{-2} \mathrm{~s}^{-1}$ ) in CON (diamond), DI-J (triangle), DI-A (circle) and DI-JA (square) for two different levels of ETo $<5.5 \mathrm{~mm} \mathrm{~d}^{-1}$ (solid) and $>5.5 \mathrm{~mm} \mathrm{~d}^{-1}$ (clear). Each point represents the average of four measures per treatment taken in 2007 and 2009. 